\title{
9. QUELLENVERZEICHNIS
}

\author{
9.1. Archivalien
}

\subsubsection{Deutsche Archive}

Bundesarchiv (BA), Berlin

Bestand Reichskanzlei

BA R43, I, 43: Staaten in Afrika, Bd. 1

BA R43, I, 654f.: Kreditwesen und Geldwirtschaft, Bde. 3f.

Bestand Auswärtiges Amt

BA R901, 23541: Wirtschaftliche Unternehmungen in Marokko und Beteiligung deutschen Kapitals an denselben

Bestand Reichsministerium des Innern

BA R1501, 53103: Marokko 2, Geheim, Handelssachen, Das marokkanische Minengesetz

Politisches Archiv des Auswärtigen Amtes (PA-AA), Berlin (früher Bonn)

Abteilung $I A$

PA-AA R15753: Marokko 4, Die marokkanische Frage, Bd. 217

PA-AA R16057: Marokko 25 Nr. 8, Bergwerke in Marokko, Bd. 19

PA-AA R16064-16079: Marokko 25 Nr. 8a, Verhandlungen in Paris über das neue Bergwerkgesetz, Bde. 1, 1a, 2-8, 8a, 9-13

PA-AA R16098: Marokko 27, Der Waffenschmuggel nach Marokko, Bd. 3

PA-AA R16309: Spanische Besitzungen in Afrika Nr. 1, Bd. 8

PA-AA R21167-21192: Der Weltkrieg Nr. 11/1, Unternehmungen und Aufwiegelungen gegen unsere Feinde (Afrikanische Besitzungen Frankreich), Bde. 1-10, 10a, 11-25

Abteilung II, Geheimakten

PA-AA R30190k: Frankreich Pol. 3, Vertreter deutscher Zeitungen und andere Deutsche bei den Rifkabylen

PA-AA R31764: Russland Pol. 19, Bolschewismus in Afrika

Abteilung II, F-M (Militär und Marine)

PA-AA R33146: F13, Massnahmen zur Verhinderung des Eintritts Reichsdeutscher in fremde Heere und Nachrichten über fremde Heere, Bd. 1

PA-AA R33398: K56, Verkauf von Kriegsmaterial nach Marokko

Abteilung II, Allgemeines

PA-AA R70181: Rechtswesen 31, Bartels-Si Hermann

Abteilung II, Frankreich

PA-AA R70636-70639: Politik 3, Politische Beziehungen zu Marokko, Bde. 1-4

PA-AA R70840-70844: Politik 13 Nr.6B, Protokolle über die Vernehmung ehemaliger französischer Fremdenlegionäre, Bde. 5-10

PA-AA R70857: Politik 13 Nr. 6E, Strafverfolgung und Verfolgung von Deutschen in der französischen Fremdenlegion vor französischen Gerichten, Bd. 1

PA-AA R70870f:: Politik 13 Nr. 6, Legionär Klems, Bde. 1f.

PA-AA R70966: Rechtswesen 15A, Der Austausch bzw. die Begnadigung in Frankreich verurteilter Deutscher und in Deutschland verurteilter Franzosen, Bd. 2

PA-AA R70975-70980: Rechtswesen 15B, Deutsche in französischen Strafkolonien, Bde. 8-13 
Abteilung II, Morokko

PA-AA R71118: Weltkrieg, Weltkrieg mit Bezug auf Marokko

Abteilung II, Tanger

PA-AA R71125-71127: Politik, Die politischen Verhältnisse in Tanger, Bde. 1-3

Abteilung II, Spanien

PA-AA R71920-71928: Politik 13 Nr. 6, Spanische Fremdenlegion, Allgemeines, Bde. 1-9

Abteilung II, Spanisch-Marokto

PA-AA R72041-72047: Politik, Allgemeine Auswärtige Politik, Bde. 1-7

PA-AA R72060: Wirtschaft, Algemeine wirtschaftliche Lage, Bd. 1

PA-AA R72063: Politik Riff-Republik, Allgemeine Politik in der Riff-Republik

Abteilung II, Wirtschaft

PA-AA R87832: Marokko Industrie 6, Bergbau, Hüttenindustrie, Bd. 2

PA-AA R87858: Marokko Schiffahrtswesen, Schiffahrtsbeziehungen Deutschlands zu Marokko

Sonderreferat Wirtschaft

PA-AA R118401-118403: Wirtschaft 1, Reichskredit für Mannesmann, Bde. 1-3

Abteilung II, Privata Frankreich

PA-AA R102941: Strafverfolgung Klems

Akten der Botschaft London

PA-AA London 554: Geheimakten Marokko, Bd. 7

Akten der Botschaft Madrid

PA-AA Madrid 112: Pol. 15, Mannesmann-Angelegenheit in Marokko (Terramons GmbH)

PA-AA Madrid 132-138: Marokko Pol. 15, Erlasse und Berichte, Bde. 39-45

PA-AA Madrid 351: Akten Konsulat Tetuan, Bd. 2

PA-AA Madrid 474: Marokko 4, Mannesmann-Interessen in Marokko, Bde. If.

Akten der Botschaft Paris

PA-AA Paris 454a-b: Marokko, Bde. 1f.

Akten der Botschaft Rom

PA-AA Rom 748: Marocco Pol. 3, Bd. 1

Nachlässe

PA-AA NL RM Gustav Stresemann, Bd. 36

PA-AA NL Walter Zechlin, Kriegstagebücher, Bd. 3

\subsubsection{Französische Archive}

Archives diplomatiques du ministère des Affaires étrangères (ADMAE), Paris

Série Maroc 1917-1940

ADMAE Maroc 98-101: Négotiations et applications

ADMAE Maroc 111-115: Papiers d'Abdelkrim

ADMAE Maroc 128-132: L'opinion publique et la question rifaine

ADMAE Maroc 133f:: Interventions de personnalités diverses

ADMAE Maroc 134f.: Gordon-Canning

ADMAE Maroc 138: Déclarations des prisonniers libérés après la reddition d'Abd el Krim

ADMAE Maroc 192-199: Dossier général 1917-1927

ADMAE Maroc 217: Affaires de Tétouan

ADMAE Maroc 219: Contrebande d'armes, Achat d'avions et de materiel de guerre par les

Riffains

ADMAE Maroc 220: Surveillance du trafic maritime

Archives nationales (AN), Paris 
Fonds particuliers, Série AP, Archives personnelles et familiales

313 AP Papiers Painlevé

AN 313 AP 244: Maroc, Rapports sur le Rif

AN 313 AP 247: Maroc

475 AP Papiers Lyautey

AN 475 AP 193: La situation au Maroc en 1925-1926

Section moderne et contemporaine, Série F7, Police générale

AN F7, 12836: Contrebande d'armes au Maroc

AN F7, 13413: Campagne du Maroc

AN F7, 14679: Armes, Dossiers de trafic ou contrebande d'armes, Maroc (Rif)

AN F7, 14978: Afrique du Nord en général, juillet 1921-mars 1939

AN F7, 14980: Maroc, Renseignements d'ordre général, action du Komintern au Maroc

(Contrebande d'armes et communisme), juin 1922-mars 1940

Archives de la prefecture de police (APP), Paris

APP BA 1678: Maroc, Affaires diverses conçernant le Riff (contrebande d'armes, recrutement d'officiers)

Bibliothèque de documentation internationale contemporaine (BDIC), Paris

BDIC Ohme Fol. A Rés 78: Dossier BDIC, France Affaires: Ohme, Koberstein. Demande de révision d'un procès en désertion de 2 sous-officiers de la Légion étrangère, entreprise en 1927 par la Ligue des droits de l'homme

Centre des archives diplomatiques (CADN), Nantes

Archives de postes diplomatiques et consulaires, Postes d'Afrique du Nord et du ProcheOrient

Légation de France au Maroc, Agence puis consulat général de France à Tanger, XLX siècle-1958

CADN Tanger A396: Le Rif, Pillages et réclamations 1892-1908

CADN Tanger A425-427: Affaires espagnoles politiques 1921-1922

CADN Tanger A435f.: Affaires allemandes, Dossier général 1890-1912

CADN Tanger A450: Mines 1901-1926

CADN Tanger A575: Intrigues allemandes, Suspects 1914-1919

CADN Tanger A1319: Zone espagnole, Melilla, Malaga 1915-1922

CADN Tanger A1321: Agissements allemands en Afrique du Nord 1915-1924

CADN Tanger B13: Consulat de France à Tetouan, Dossier général 1917-1922

CADN Tanger B30f.: Affaires espagnoles 1917-1928

CADN Tanger B44: Mines, Mines du Rif, Règlement minier en zone espagnole 1914-1923

CADN Tanger C37-40: Guerre du Rif 1924-1927

CADN Tanger D65: Affaires allemandes, Dossier général 1921-1939

CADN Berlin B44: Maroc 1913

CADN Berlin B497: Maroc 1921-1925

CADN Berlin C134: Organisation allemande d'espionnage et contre-espionnage en Espagne 1920-1925

CADN Caire 103: Maroc 1904-1929

CADN Londres C517-519: Dossier général 1920-1925

CADN Londres C520: Contrebande par Gibraltar, Concessions des frères Mannesmann, Expéditions de navires anglais par les ports marocains

CADN Londres C523-528: Tanger 1921-1926

CADN Londres C536: Affaires musulmanes 1922-1924

CADN Madrid B466: Maroc, Mines, Groupe Mannesmann 1903-1918

CADN Madrid C258-259: Dossier general 1918-1925 
CADN Madrid C261: Dossier général (Affaires du Riff) 1925-1926

CADN Madrid C263: Dossier général (Propagande d'Abd el Krim) 1922-1942

CADN Madrid C270-275: Événements dans la zone espagnole 1918-1942

CADN Madrid C305: Intérêts allemands et anglais 1918-1942

CADN Madrid C312: Maroc, Mines 1919-1935

CADN Rome A453: Maroc, Dossier général 1921-1937

Protectorats et mandats, Protectorat Maroc, Cabinet diplomatique

CADN Maroc CD 741: Agissements allemands au Maroc 1920-1934

Protectorats et mandats, Protectorat Maroc, Direction des affaires indigènes, Inv. 8

CADN Maroc DAI 187-192: Rif 1922-1926

CADN Maroc DAI 193: Rif, Opérations militaires 1924-1925

CADN Maroc DAI 194f:: Rif 1925

CADN Maroc DAI 196f:: Rif, Abd-el-Krim 1925-1926

CADN Maroc DAI 198f.: Rif, Abd-el-Krim 1926

CADN Maroc DAI 220f.: Action allemande 1907-1916

Protectorats et mandats, Protectorat Maroc, Direction de l'intérieur

CADN Maroc Direction de l'intérieur 842: Dossiers nominatifs (Klems)

Centre des archives d'Outre-Mer (CAOM), Aix-en-Provence

Algérie Cabinet militaire

CAOM Algérie 1CM1: Rif, Frontière marocaine, Bâtiments suspects 1925

Algérie Série $H$

CAOM Algérie 9H93: Affaires espagnoles en liaison avec les événements du Riff 19211923

CAOM Algérie 30H63: Port Say, Rif, Contrebande 1904-1913

CAOM Algérie 30H86f:: Guerre du Rif

Série Colonies $H$, Établissements pénitentiaires coloniana (XIXe-XXe siècles)

CAOM Colonies H4417, Mle. 50321

Archives privées et entrées par voie extraordinaire

Série APOM

CAOM 10 APOM 295: L'affaire riffaine (Robert Montagne)

Service historique de l'armée de terre (SHAT), Vincennes

Série $3 H$, Maroc

SHAT 3H102: Notes de la SR, Contrebande d'armes, agissements étrangers et aide aux Riffains

SHAT 3H133: Politique espagnol au Maroc, Section allemande, Situation militaire au Maroc espagnol

SHAT 3H134: Rapport de l'attaché militaire à Madrid sur les affaires du Rif

SHAT 3H135: Notes de la SR, Transmis par les consuls de France à Tanger, Tétouan, Larache sur la situation au Maroc espagnol 1925-1927

SHAT 3H146: Déchiffrement et traduction de télégrammes espagnols 1917-1925

SHAT 3H442: Interrogatoires de prisonniers riffains et de prisonniers europeens et indigenes évadés du Riff 1925-1926

SHAT 3H443: Effectifs rifains, Postes du Rif 1925-1926

SHAT 3H602: Documents émanant de la Résidence, Renseignements sur Abd-el-Krim et son entourage

SHAT 3H1102-1 104: Région de Taza, Cercles et sous-secteurs

SHAT 3H1154: $1^{\text {ere }}$ division de marche du Maroc, J.M.O

SHAT 3H1557: Événements du Maroc espagnol, Enseignements de la guerre du Rif

SHAT 3H1558: Documentation sur le Rif, Abd-el-Krim et son entourage

SHAT 3H1559: Bulletins de renseignements 
SHAT 3H1560-1561: Correspondances, renseignements, notices sur les chefs riffains

Série J, Archives de la justice militaire

SHAT 12J3797: Dossier Klems Joseph

Série 7N, État-major de l'armée (E.M.A.)

SHAT 7N2757: Rapports des attaches militaires, Espagne

\subsubsection{Britische Archive}

Public Record Office (PRO), London

Air Staff

PRO-AIR 5, 722: A Study of the Air Aspect of the France-Riff War 1925-1926, by F./Lt.

D.L. BLACKFORD 1930

Board of Trade

PRO-BT 31, 19288, 108057: Anglo-Moroccan Mining Syndicate, Ltd. 1910

PRO-BT 31, 20509, 120595: Morocco Riff Mining Syndicate, Ltd. 1912

PRO-BT 31, 20673, 122048: British Morocco Co., Ltd. 1912

PRO-BT 31, 24047, 150343: French Iron Ore Company 1918

PRO-BT 31, 25262, 160911: Gardiner Shipbuilding and Engineering Company 1919

PRO-BT 31, 27226, 181891: International Oil Suppliers, Ltd.

PRO-BT 31, 28584, 198934: Melilla Mining Co., Ltd. 1924

PRO-BT 31, 33790, 125985: Morocco Minerals Syndicate 1912

Cabinet, Committee of Imperial Defence

PRO-CAB 4, 12, 554B: Committee of Imperial Defence, Air Staff Note on the Situation in Morocco

PRO-CAB 4, 12, 566B: Committee of Imperial Defence, Memorandum of the First Lord of the Admiralty

Colonial Office

PRO-CO 91, 482: Gibraltar Despatches 1923

Foreign Office

PRO-FO 174, 299, 33: Tangier, Mining Denunciations 1920

PRO-FO 174, 303, 74: Tangier, Bonich, Nationality 1924

PRO-FO 174, 303, 76: Riff Republic Movement

PRO-FO 174, 305, 88: Gordon-Canning 1926

PRO-FO 368, 433: Morocco 1910

PRO-FO 368, 1332f:: Morocco 1915

PRO-FO 368, 1766: Morocco 1917

PRO-FO 368, 2150f:: Morocco 1919

PRO-FO 369, 1814: Consular, Spain 1922

PRO-FO 371, 930-935: Morocco 1910

PRO-FO 371, 1691-1694: Morocco 1913

PRO-FO 371, 2044-2049: Morocco 1914

PRO-FO 371, 2414f:: Morocco 1915

PRO-FO 371, 2713-2714: Morocco 1916

PRO-FO 371, 3252-3253: Morocco 1918

PRO-FO 371, 3842-3846: Morocco 1919

PRO-FO 371, 4511-4534: Morocco 1920

PRO-FO 371, 6581: Turkey 1921

PRO-FO 371, 7066-7086: Morocco 1921

PRO-FO 371, 8341-8356: Morocco 1922

PRO-FO 371, 9114: Turkey 1923 
PRO-FO 371, 9176: Turkey 1923

PRO-FO 371, 9469-9474: Morocco 1923

PRO-FO 371, 9866: Germany 1924

PRO-FO 371, 10223: Turkey 1924

PRO-FO 371, 10581-10586: Morocco 1924

PRO-FO 371, 11074-11083: Morocco 1925

PRO-FO 371, 11907-11921: Morocco 1926

PRO-FO 371, 12687-12694: Morocco 1927

PRO-FO 371, 13871: Egypt and Sudan 1929

PRO-FO 371, 20501: Morocco 1936

PRO-FO 371, 21263-21265: Morocco 1937

PRO-FO 371, 21305f.: Spain 1937

PRO-FO 371, 49362: Morocco 1945

PRO-FO 372, 1407: Treaty, General 1920

PRO-FO 372, 2092: Treaty, Nationality 1924

PRO-FO 372, 2245: Treaty, Nationality 1926

PRO-FO 372, 2344: Treaty 1927

PRO-FO 636, 7: Tetuan 1924

Home Office

PRO-HO 45, 12067: Aviation, Export of Aeroplane to Riff Rebels in Morocco, Law Officers' Opinion of Measures for Prevention

Minitions of Wor

PRO-MUN 4, 6142: Prevention of Exports of Aeroplanes and Munitions to Riff Rebels in Spanish Morocco 1921 Aug 19-1922 Aug 17

British Library, London

BL, Northcliffe Papers, Add. 62252

India Office Reference Library (IORL), London

Series L, P\&J, Public and Judicial Department: Separate Files

IORL, P\&J, 12, 226, 1625 (1924): East-West Circle, London

IORL, P\&J, 12, 230, 1671 (1924): Reports on UK support committee for Muslim Riff Fighters in Morocco

Series $L, P \& S$, (Political and Secret Papers)

IORL, P\&S, 11, 259, 2500 (1925): Sympathy of Indian Muslims with the cause of Abdul Karim 1924-1926

Times Newspapers Library Archives (TNLA), London

Walter Burton Harris Papers

TNLA, Harris, BNS, 2: Correspondence between Harris, Walter Burton and Borghetti, R. 1925; Correspondence between Harris, Walter Burton and Chamberlain, Austen 19221923; Correspondence between Harris, Walter Burton and Clive, Harold (Sir) 1925-1926; Correspondence between Harris, Walter Burton and Krim, Abdel 1908, 1911, 1923-1926

George Dawson Papers

TNLA, GGD, 1: Correspondence between Dawson, George Geoffrey and Harris, Walter Burton 1915-1919, 1922-1931

Ralph Deakin Papers

TNLA, RD, 1, Deakin: Correspondence between Deakin, Ralph and Harris, Walter Burton 1922-1933; Correspondence between Deakin, Ralph and De Caux, E.G. 1921-1949 


\section{Harold Williams Papers}

TNLA, BNS, 1, Williams: Correspondence between Williams, Harold and Harris, Walter Burton 1922-1928; Correspondence between Williams, Harold and De Caux, E.G. 1924 1927

\subsubsection{US-Amerikanische Archive}

Hoover Institution Archives, Stanford

BARBÉ, Henri, Souvenirs, Ms. 0.O., ca. 1950 (Kopie)

National Archives and Records Administration (NARA), Washington

Records of the Department of State Relating to Internal Affairs of Morocco 1910-1929

Political Affairs

NARA 881.00, 1057, 393 (Kopie)

NARA 881.00, 1196 (Kopie)

\subsection{Gedruckte Quellen}

ABRAMOWSKI, Günter (Bearb.), Die Kabinette Marx III und IV 1926-1928, Bd. 1, Boppard 1988 (Akten der Reichskanzlei, Weimarer Republik, 10).

ARMIÑan, José M. und Luis de (Hg.), Epistolario del dictador. La figura del General Primo de Rivera, trazada por su proprio mano, Madrid 1930.

Auszug aus dem geheimen Bericht von Hauptmann Grauert und Leutnant Jeschonnek über die Reise nach Spanien von April bis Juni 1925, in: KUNZ, MŨLlER, Giftgas, S. 199-211.

BussmanN, Walter (Hg.), Akten zur deutschen auswärtigen Politik 1918-1945, Ser. A, Bd. 13, Göttingen 1995.

Das Flammenzeichen von Palais Egmont. Offizielles Protokoll des Kongresses gegen koloniale Unterdrückung und Imperialismus, Brüssel, 10.-15. Februar 1927, hg. von der Liga gegen Imperialismus und für nationale Unabhängigkeit, Berlin 1927.

Documenti diplomatici italiani, hg. vom Ministerio degli affari esteri, Ser. 7, Bde. 3-5, Rom 1959-1967.

Dokumente der Friedensbewegung. Beschlüsse des 24. Weltfriedenskongresses, in: Die Friedenswarte 25 (1925) S. 316-319.

LePSIUS, Johannes, MENDELSSOHN-BARTHOLDY, Albrecht, THIMME, Friedrich (Hg.), Die große Politik der europäischen Kabinette 1871-1914, Bd. 29: Die zweite Marokkokrise 1911, Berlin ${ }^{2} 1927$.

MedLICOTT, William N. u.a. (Hg.), Documents on British Foreign Policy 1919-1939, Series IA, Bd. 1, London 1966.

MINUTH, Karl-Heinz (Bearb.), Die Kabinette Luther I und II 1925-1926, Bd. 2, Boppard 1977 (Akten der Reichskanzlei, Weimarer Republik, 9).

MONETA, Jakob, Die Kolonialpolitik der französischen KP, Hannover 1968. 
Papers Relating to the Foreign Relations of the United States 1925, hg. vom Department of State, Bd. 2, Washington 1940.

Sixth Annual Report 1923, hg. von der British Merchant's Morocco Association, London 1923.

Who's Who 78-95 (1926-1943), London 1926-1928.

Who Was Who, Bde. 3-7, London 1947-1981.

Who Was Who in America, Bde. 1-4, Chicago 1943-1968.

\title{
9.3. Ausgewertete Zeitungen und Zeitschriften
}

\author{
A.B.C. (1925) \\ Action française (1925) \\ Al-Moghreb al Aksa, Al-Moghreb al Aksa \& Tangier Gazette (1919-1926) \\ Annales tangéroises (1925) \\ Bergedorf-Sander Volksblatt (1924) \\ Bergische Tageszeitung (1942) \\ Berliner Börsen-Courier (1925-1927) \\ Berliner Lokal-Anzeiger (1925-1926) \\ Berliner Tageblatt (1925-1929) \\ Berliner Zeitung (1924-1926, 1930) \\ Blanco y Negro (1921-1927) \\ Boletín oficial de la zona de protectorado español en Marruecos (1918-1927) \\ Bulletin du Comité de l'Afrique française (1909-1927) \\ Bulletin international des sociétés de la Croix-Rouge (1921-1926) \\ Chronique de l'Institut colonial français (1925) \\ Contemporary Review (1921-1926) \\ Cornhill Magazine (1926) \\ Current History Magazine (1921-1926) \\ Daily Mail (1925-1926) \\ Daily Telegraph (1921-1926) \\ Das Notgeld (1925) \\ Das Tagebuch (1925-1926) \\ Der Koloniale Freiheitskampf (1926) \\ Der Tag (1909, 1925-1926) \\ Der Weltspiegel (1930) \\ Deutsche Allgemeine Zeitung (1925-1927) \\ Deutsche Bergwerkszeitung (1936) \\ Deutsche Marokko-Korrespondenz (1909) \\ Deutsche Zeitung (1925-1926) \\ Deutsches Offiziersblatt (1925) \\ Die Umschau (1925-1926) \\ Die Weltbühne (1921-1926)
}


Die Woche (1925-1926)

Düsseldorfer Nachrichten (1921-1927)

Écho de Paris (1921-1926)

Écho du Maroc (1925-1927)

Éclair (1921-1926)

Ere nouvelle (1925)

Europe nouvelle (1925)

Figaro (1925-1926)

Foreign Affairs, London (1921-1926)

Foreign Affairs, New York (1925-1926)

Foreign Policy Association, Information Service (1926)

Hamburger Anzeiger (1925)

Hamburger Correspondent (1925)

Hamburger Echo (1924)

Hamburger Fremdenblatt (1921-1924)

Hamburger Nachrichten (1924)

Hamburger Volkszeitung (1924)

Homme libre (1925-1926)

Humanité (1921-1927)

Illustrated Sunday Herald (1925)

Illustration (1925-1926)

Internationale Presse-Korrespondenz (1925-1926)

Intransigeant (1925-1926)

Irish Independent (1925)

Islamic Review (1921-1926)

Journal (1921-1926)

Kölner Tageblatt (1925)

Kölnische Volkszeitung (1927)

Kölnische Zeitung (1925-1926)

Leipziger Jüdische Zeitung (1925)

Leipziger Neueste Nachrichten (1925)

Liberté (1925)

Living Age (1921-1926)

Literary Digest (1921-1926)

Manchester Guardian (1921-1926)

Matin (1922-1927)

Mecklenburger Warte (1924)

Militär-Wochenblatt (1925)

Morocco (1921-1926)

Moslem World (1921-1926)

Muslim Outlook (1925)

Neue Berliner Zeitung (1925)

Neue Freie Presse (1925-1926) 
Neue Zürcher Zeitung (1925-1926)

New York Herald (1925)

New York Times (1921-1926)

O Jornal (1925)

Euvre (1921-1926)

Paris-Midi (1925)

Patriot (1926)

Petit Journal (1921-1926)

Petit Parisien (1926)

Petroleum (1921-1926)

Populaire (1927)

Quotidien (1925-1926)

Radio-Umschau (1925)

Renseignements coloniaux et documents (1909-1927)

Rote Fahne (1921-1926)

Round Table (1925)

Scientific American (1905)

Sol (1922)

Springfield Republican (1926)

Tablettes marocaines (1925-1926)

Tägliche Rundschau (1925-1927)

Temps (1921-1926)

Tiempo (1921)

Times $(1913,1918,1921-1927,1934,1940,1948)$

Vigie marocaine (1927)

Volkszeitung (1925)

Vossische Zeitung (1914, 1924-1927)

Weser-Zeitung (1925)

Wissen und Wehr (1924-1926)

\subsection{Zeit- und Augenzeugenberichte}

ABDELKRIM, Memoiren. Mein Krieg gegen Spanien und Frankreich, Dresden 1927.

ANIK, A., Correspondence (Leserbrief, 27.1.1925), in: Islamic Review 13 (1925) S. 120.

ARDEMAGNI, Mirko, Abd el Krim asserisce a un nostro inviato che egli, volendo, sarebbe gia a Fez, in: Popolo d'Italia, 16.6.1925.

ARMENGAUD, Paul F., Quelques enseignements des campagnes du Riff en matière d'aviation 1925-1926, Paris 1928.

ARNALL, John, Correspondence, in: Al-Moghreb al Aksa, 25.10.1919. 
ARTBAUER, Otto C., Die Rifpiraten und ihre Heimat. Erste Kunde aus verschlossener Welt, Stuttgart 1911.

BAKER, Roy, Penal Battalion, London 1934.

BarruCAND, Victor, La Guerte du Rif, Paris 1927.

BARRY, Arthur J., Railway Expansion in China and the Influence of Foreign Powers on its Development, London 1910.

BARTELS, Albert, Auf eigene Faust. Meine Erlebnisse vor und während des Weltkrieges in Marokko, Leipzig 1925.

BELBENOit, René, Dry Guillotine. Fifteen Years among the Living Dead, Maidstone 1973 (Nachdr. d. Ausg. New York 1938).

BENNETT, Ernest N., With the Turks in Tripoli. Being Some Experiences in the Turco-Italian War of 1911, London 1912.

-, Correspondence. The Red Cross and the Riff, in: Manchester Guardian, 23.1.1925.

BERTHOD, A., Vers la paix au Maroc, in: Petit Journal, 19.4.1926.

BERTHON, André, Abd el Krim et Poincaré, in: Humanité, 12.5.1925.

BEVAN, John A., Spain and Morocco. The Rif Campaign. I: The Great Debacle, in: Morning Post, 22.10.1923.

-, Spain and Morocco. The Rif Campaign. II: Abdul Krim, in: Morning Post, 23.10.1923.

-, Spain and Morocco. The Rif Campaign. III: Spain and the Future, in: Morning Post, 24.10.1923.

BLÜCHER, Wipert von, Am Rande der Weltgeschichte. Marokko, Schweden, Argentinien, Wiesbaden 1958.

BolChUT, Général, Campagne du Rif 1925-1926. Officiers espagnols et français au Maroc, in: Revue de deux mondes 41 (1937) S. 304-335.

BONNET-DEVILliers, René, La Guerre du Rif. Ce que j'ai vu au Maroc, Paris 1926.

BOOTH, Daniel, Introduction, in: Bernd TERHORST, With the Riff Kabyles, London 1926, S. 13-22.

BOURMANCÉ-SAY, Daniel, Une véritable guerre d'indépendance, in: Intransigeant, 28.7.1921.

-, La population de Melilla massacre les musulmans, in: Écho de Paris, 30.7.1921.

-, Les représailles espagnoles ne font que redoubler le fanatisme des insurgés, in: Écho de Paris, 3.8.1921.

-, Les Espagnols temporisent, in: Écho de Paris, 10.8.1921.

-, Allouche le Corsaire, âme de la révolte des Maures. Une autre puissance viendra-t-elle au secours des conquistadors du Riff, in: Intransigeant, 18.8.1921.

-, Quelques épisodes de la lutte des Espagnols contre les Riffains, in: Écho de Paris, 25.8.1921.

-, Une heure avec Allouch le Corsaire, le vainqueur du général Navarro, in: Intransigeant, 10.9.1921.

-, L'offensive espagnol aurait échoué, in: Intransigeant, 25.9.1921.

-, Une mission anglaise econduite par les Riffains, in: Intransigeant, 29.9.1921.

-, Le secret de l'échec espagnol. Union sacrée des tribus, commandement unique, armement sérieux, in: Intransigeant, 4.10.1921.

-, Les espagnols ont un succes, in: Intransigeant, 5.10.1921.

-, Une lettre autographe de Si-Mohamed ben Abd-El-Krim, in: Intransigeant, 13.12.1921.

-, Au Maroc espagnol, in: Intransigeant, 15.12.1921.

-, Dans le Riff Marocain. Un récit émouvant du revers local que viennent de subir les Espagnols, in: Intransigeant, 18.1.1922.

-, Une ruse riffaine, in: Intransigeant, 25.1.1922. 
CUNNINGHAME GRAHAM, Robert B., The Spaniards and the Riff (Leserbrief, 8.10.1925), in: Manchester Guardian, 9.10.1925.

DAMIDAUX, Charles J., Combats au Maroc 1925-1926, Paris 1928.

DegenKolbe, Kurt (unter dem Pseudonym ABdullaH), Erlebnisse an der Seite Abd el Krims. Was der Dolmetscher des Sidna erzählt, in: Deutsche Zeitung, 7.3.1926.

-, Vom Schusterjungen zum Adjutanten Abd el Krims. Selbsterlebtes erzählt, Berlin 1928.

DixON-JOHNSON, Charles F., The British Red Crescent Society (Leserbrief, 10.12.1912), in: Times, 28.12.1912.

-, The Turkish Crisis, in: Foreign Affairs 4 (1922-1923) S. 83.

-, Riff Independence (Leserbrief, 30.7.1925), in: Manchester Guardian, 1.8.1925.

DRUMMOND-HAY, Alice, ELSON, H.P., Correspondence (Leserbrief), in: Al-Moghreb al Aksa \& Tangier Gazette, 10.4.1926.

Du TAlLlis, Jean, Au cour du Rif inconnu, in: L'Illustration 80 (1922) S. 195-199, S. 226229.

-, Behind the Moorish Lines, in: The Living Age 315 (1922) S. 164-170.

-, Le nouveau Maroc, Paris 1923.

Duclos, Jacques, Mémoires 1896-1934. Le chemin que j'ai choisi. De Verdun au Parti communiste, Paris 1968.

Ex-Légionnaire 1384 of the Légion Étrangère, Hell Hounds of France, London 1932.

FIELD, Arthur, Turko-British Entente, in: The Asiatic Quarterly Review 2 (1913) S. 249 253.

-, Terms from Abdel Krim (Abdruck eines Leserbriefes aus dem "Daily Express«, 25.11.1925), in: Al-Moghreb al Aksa \& Tangier Gazette, 12.12.1925.

-, Neutrality in Tangier, in: Foreign Affairs 7 (1925-1926) S. 84.

-, France and the Riff. Captain Gordon-Canning's Mission, in: Foreign Affairs 7 (19251926) S. 234f.

-, The Morocco War (Leserbrief, 3.3.1926), in: Manchester Guardian, 4.3.1926.

FORBES, Rosita, Red Horizon, London 1932.

FreEMANTLE, Anne, Loyal Enemy, London 1938.

FRY, Anna R., Tangier To-day, in: Foreign Affairs 7 (1925-1926) S. 68f.

-, Ein Quäker-Wagnis. Die abenteuerliche Geschichte eines Friedensfeldzuges in und nach dem Weltkriege, Nürnberg 1933.

GABRiELLI, Léon, Abd-el-Krim et les événements du Rif 1924-1926, Casablanca 1953.

GANTE, Jaime M. de, El cautiverio en Axdir. La vida de los prisioneros, in: Blanco y Negro, 8.1.1922.

GARDINER, Charles A.P., My Own Story. Captain Gardiner's First Sensations Under Sea, in: Illustrated Sunday Herald, 7.6.1925.

-, Kidnapping a Crew for a 2,000-Mile Trip, in: Illustrated Sunday Herald, 14.6.1925.

-, Grand Guignol Drama Under Water, in: Ilustrated Sunday Herald, 21.6.1925.

-, Kitchener's Wire About the Wild Men, in: Illustrated Sunday Herald, 28.6.1925.

-, My Arrest for Minefield Disaster, in: Illustrated Sunday Herald, 5.7.1925.

-, My Under-Sea Battle with an Octopus, in: Illustrated Sunday Herald, 12.7.1925.

-, Mystery Ship Thrills in the Great War, in: Illustrated Sunday Herald, 19.7.1925.

-, I Become Ambassador to Riffs, in: Illustrated Sunday Herald, 26.7.1925.

-, My Escape in Lifeboat from Spanish Bombs, in: Illustrated Sunday Herald, 2.8.1925.

-, A Correction (Leserbrief), in: Al-Moghreb al Aksa \& Tangier Gazette, 28.11.1925.

GARDINER, Ina, Peril of Floods, in: Illustrated Sunday Herald, 26.7.1925.

-, My Life as Abd-el-Krim's Guest in the Riff, in: Illustrated Sunday Herald, 9.8.1925. 
-, How Abd-el-Krim Rules the Riffians, in: Illustrated Sunday Herald, 16.8.1925.

GASSETT, Arthur, Correspondence (Leserbrief), in: Al-Moghreb al Aksa \& Tangier Gazette, 31.10.1925.

GHISOLFI, Pierre, Abd-el-Krim, in: Tablettes marocaines, 4.10.1924.

GODED LLOPIS, Manuel, Marruecos. Las etapas de la pacificación, Madrid 1932.

GORDON-CANNING, Robert, Spain and Morocco (Leserbrief), in: Times, 12.9.1924.

-, Tangier and Morocco, in: Contemporary Review 127 (1924) S. 177-184.

-, The Riffis - Their History and Their Cause. A Lecture Given before the Near and Middle

East Association Last Month, in: African World, North African Monthly Supplement No. 1, 15.11.1924.

-, Peace Be Upon Us All, in: Islamic Review 12 (1924) S. 213-216.

-, Correspondence (Leserbrief), in: Islamic Review 12 (1924) S. $219 f$.

-, The Riff, in: Foreign Affairs 6 (1924-1925) S. 209-211.

-, The Powers and Morocco, in: Foreign Affairs 6 (1924-1925) S. 286f.

-, Raisuli the Oft-Dead. A Romantic-Tragic Career, in: Westminster Gazette, 7.5.1925.

-, The Riff (Leserbrief, 24.7.1925), in: Manchester Guardian, 27.7.1925.

-, Riff Independence (Leserbrief, 26.7.1925), in: Manchester Guardian, 29.7.1925.

-, The Future of the Riff (Leserbrief, 31.8.1925), in: Manchester Guardian, 1.9.1925.

-, The French Peace Terms to the Riff (Abdruck eines Leserbriefes aus der »Westminster Gazette«, 18.8.1925), in: Al-Moghreb al Aksa \& Tangier Gazette, 5.9.1925.

-, The Peace Terms Offered to the Riffs (Leserbrief, 6.10.1925), in: Manchester Guardian, 7.10.1925.

-, Correspondence (Leserbrief), in: Al-Moghreb al Aksa \& Tangier Gazette, 19.12.1925.

-, Peace Terms for the Riff, in: Foreign Affairs 7 (1925-1926) S. 67f.

-, Captain Gordon-Canning and the Riff (Leserbrief), in: Foreign Affairs 7 (1925-1926) S. 305.

-, Correspondence (Leserbrief), in: Al-Moghreb al Aksa \& Tangier Gazette, 30.1.1926.

-, Correspondence (Leserbrief), in: Al-Moghreb al Aksa \& Tangier Gazette, 6.2.1926.

-, France, Spain, and Abdel Krim (Leserbrief, 26.5.1926), in: Manchester Guardian, 29.5.1926.

-, England and Egypt, in: Times, 4.5.1929.

-, Boabdil, or "The Twilight of Granada« and Other Poems, London 1930.

GRIFFIN, Ernest H., Adventures in Tripoli. A Doctor in the Desert, London 1924.

-, Correspondence (Leserbrief), in: Manchester Guardian, 2.1.1925.

HAARDT, Georges-Marie, AUDOUIN-DUBREUIL, Louis, La première traversée du Sahara en automobile, Paris 1923.

HAENTSCHEL, Otto, In der Hölle von Tetuan. Mit den Spaniern gegen die Marokkaner, in: Vossische Zeitung, 2.5.1925.

-, Mein Schreckensjahr in der spanischen Fremdenlegion, in: Kreuz-Zeitung, 5.6.1925.

HaIG ThOMAS, Margaret (The Viscountess RHONDDA), This Was My World, London 1933.

HARRIS, Walter B., A Well-Known Trick, in: Times, 6.12.1913.

-, Spain's Moroccan War. Moorish Leader's Challenge. Charges of Cruelty, in: Times, 30.5.1922.

-, A Rifi Appeal, in: Times, 26.6.1922.

-, The Rif Rising. French Deny Spanish Charges, in: Times, 11.8.1923.

-, Spain and the Riff. Two Unpublished Letters, in: Times, 9.6.1924.

-, The Moroccan Campaign. Stories of British Aid for Rifis. Propaganda Tales, in: Times, 11.9.1924.

-, Moroccan War. Statement by Rif Leader, in: Times, 13.10.1924.

-, Captured Englishman Released, in: Times, 14.10.1924.

-, Work for Red Crescent in Morocco. Political Considerations, in: Times, 24.10.1924. 
-, France and Morocco. Marshall Lyautey's Warning, in: Times, 10.11.1924.

-, France and Morocco. Abdel Krim's Claims, in: Times, 11.11.1924.

-, Conditions in the Rif. English Travellers' Report, in: Times, 3.12.1924.

-, The Rifi Revolt. Story of British Support, in: Times, 31.1.1925.

-, The Warfare in the French Zone. A Difficult Campaign, in: Times, 10.6.1925.

-, Moroccan Issue. Basis for Peace Negotiations. Rifi Nationalism, in: Times, 16.6.1925.

-, Rif Coast Fortified. Warning to Merchantmen, in: Times, 19.6.1925.

-, Abd-el-Krim's Reply to Peace Offer. Independence Claim, in: Times, 27.7.1925.

-, Abd-el-Krim and the Spanish Envoys at Tetuan, in: Times, 30.7.1925.

-, Abd-el-Krim and Spain. Envoys at Tetuan, in: Times, 3.8.1925.

-, Rifi Envoys and Peace Terms. Report to Abd-el-Krim, in: Times, 4.8.1925.

-, Abd-el-Krim and the Peace Terms, in: Times, 7.8.1925.

-, Gun-Running on Rif Coast, in: Times, 3.9.1925.

-, Spanish Landing Alhucemas, in: Times, 8.9.1925.

-, Rifi Reports. Fighting Near Tetuan, in: Times, 9.9.1925.

-, Abd-el-Krim's Letter, in: Times, 9.9.1925.

-, Gun-Fire Heard in Tangier, in: Times, 17.9.1925.

-, The Defection of Tazzi's Sons, in: Times, 19.9.1925.

-, Abd-el-Krim and the Spanish Advance, in: Times, 29.9.1925.

-, Abd-el-Krim's Offer to Treat. A British Intermediary, in: Times, 18.12.1925.

-, Rifi Proposals for Peace. Abd-el-Krim's Demands, in: Times, 22.12.1925.

-, Abd-el-Krim's Power. Organization in the Rif, in: Times, 29.12.1925.

-, Captain Canning and Abd-el-Krim, in: Times, 30.1.1926.

-, Captain Canning, in: Times, 8.2.1926.

-, The Rif Case. A Letter from Abd-el-Krim, in: Times, 17.3.1926.

-, Moroccan War. Abd-el-Krim's Plans, in: Times, 29.3.1926.

-, Morocco Peace Hitch. Conditions Disputed, in: Times, 21.4.1926.

-, The Moroccan Parleys, in: Times, 26.4.1926.

-, Spanish Policy Defined, in: Times, 27.4.1926.

-, The Moroccan Conference. Preliminary Sessions, in: Times, 28.4.1926.

-, Security in the Rif. The Question of Disarmament, in: Times, 30.4.1926.

-, Rifis' Reply. Moroccan Peace Deadlock, in: Times, 1.5.1926.

-, Next Phase in Morocco, in: Times, 3.5.1926.

-, Rifi Appeals to the British. Krim's European Advisers, in: Times, 27.5.1926.

-, Better Outlook in Morocco, in: Times, 7.6.1926.

-, Spain and Tangier. A Thorn in the Flesh, in: Times, 18.3.1927.

-, Tangier Problem Dangers. A Base of Intrigue, in: Times, 4.6.1927.

-, France, Spain, and the Rif, London 1927.

HoBHOUSE, Charles, Aims and Prospects in the Riff, in: Manchester Guardian, 31.8.1925.

-, Relieving Refugees from the Riff, in: Manchester Guardian, 1.9.1925.

-, The Situation in Morocco, in: Contemporary Review 129 (1925) S. 437-445.

HOEBEL, Heinz, Flucht aus der spanischen Legion! Erlebnisse eines Deutschen im Riffgebiet, in: Mecklenburger Warte, 21.12.1924.

HUBER, Albert, Als Fremdenlegionär in Marokko, Zürich 1930.

JussuF, Mustafa ben, Ein Düsseldorfer bei Abd el Krim. Das Schicksal des Fremdenlegionärs Josef Klems, in: Düsseldorfer Nachrichten, 25.6.1926.

-, Der Mensch Abd el Krim, in: Vossische Zeitung, 14.7.1926.

-, Die fremden Offiziere bei Abd el Krim, in: Düsseldorfer Nachrichten, 22.8.1926.

KEENE, Emily, My Life Story, London 1911. 
KenWORTHY, Joseph M., Moslems and the Moroccan War. France, Spain and the Riffs. Great Britain's Interest, in: The Referee, 15.5.1925.

KHORAT, Pierre, La fin d'Abd-el-Krim, in: Correspondant 304 (1926) S. 321-357.

KLOSE, Fritz, Marschier oder krepier! Leiden und Laster der Legion, Berlin 1932.

LA GARDE, Louis de, The Rif Rising, in: Times, 25.8.1923.

-, The Moroccan War. Visit to Abdul Krim. Despot of the Rif, in: Times, 15.9.1923.

LANGleT, Hans A, Abdel Krim's Views on a Riff Peace, in: Manchester Guardian, 29.4.1926.

-, Life in the Riff, in: Manchester Guardian, 1.5.1926.

-, How the Riffis Fight, in: Manchester Guardian, 4.5.1926.

-, Riff. Strövtåg i Abd-el-Krims sultanet, Stockholm 1927.

LAURE, Auguste M., La victoire franco-espagnole dans le Rif, Paris 1927.

LEGEY, Georges, Ce que j'ai vu au Maroc, juin-juillet 1925. Quelques vérités sur la Guerre du Riff, Nancy 1925.

LEON, Henri M., The Geology of the Isle of Man, London 1915.

-, Sheikh Haroun Abdullah, a Turkish Poet, and His Poetry, Blackburn 1916.

-, The Chelonia or »Shield Reptiles of Palestine«, London 1917.

-, Influenza. Its History, Symptology and Treatment, London 1921.

LÖHNDORFF, Ernst F., Afrika weint. Tagebuch eines Legionärs, Bremen 1930.

LORENSEN, Alfred, Mit der Legion in Syrien und Marokko, in: Süddeutsche Monatshefte 23 (1925) S. 416-418.

LORENZ, Fritz, Deutsche Frontkämpfer in Marokko. Söldner und Deserteur der spanischen Fremdenlegion, Berlin, Leipzig 1926.

MANDER, Lionel H., Spain and the Rif (Leserbrief), in: Times, 24.6.1924.

MARSILlaC, Jacques de, Un voyage au coeur du Riff sur le chemin qui mène vers Abd el Krim, in: Journal, 18.1.1925.

-, "Je désire vivement m'entendre avec la France et je ferai tout ce qui est possible pour y réussiru, in: Journal, 20.1.1925.

MATTAR, Ahmed H., Abd el Krim und Europa, in: Mitteilungen des Bundes der Asienkämpfer 8 (1925), S. 31.

-, Der Kampf ums Rif, in: Der Koloniale Freiheitskampf, 15.2.1926.

-, Memorandum der Rifkabylen an den Völkerbund, in: Der Koloniale Freiheitskampf, 15.2.1926.

-, Sindbad min as-Sudan, Khartum ${ }^{2} 1976$.

MENTHA, Henri, Mission à Tanger, in: Bulletin international des sociétés de la Croix-Rouge 56 (1925) S. 971-981.

MEYER, Walter, Dreitausend Kilometer barfuß durch Afrika. Erlebnisse eines jungen Deutschen in der spanischen Fremdenlegion während der Kämpfe mit den Rifkabylen, Stuttgart 1929.

MILLER, Webb, Ich fand keinen Frieden, Berlin 1938.

MOREA, Alfredo, La guerra marochina vista dal campo di Abd-el-Krim, in: Vocce repubblicana, 4.11.1925.

Mowrer, Paul S., Une visite chez Abd el Krim, adversaire de l'Espagne, in: L'Europe nouvelle 13 (1924) S. 1522-1524.

-, The House of Europe, Boston 1945.

MUNDEY, S. Cyril B., Correspondence (Leserbrief), in: Al-Moghreb al Aksa \& Tangier Gazette, 4.10.1924.

NEF, Werner, Im Kampfe gegen die Rifkabylen. Erlebnisse eines Schweizers in der Fremdenlegion während des Aufstandes im französischen Rif, Weinfelden 1927. 
NIELSEN, Aage K., In der marokkanischen Kriegszone. In den Hauptquartieren der Spanier und der Franzosen, in: Berliner Tageblatt, 4.6.1925.

OHLE, Fritz, Der kleine Krieg in Afrika, Berlin 1905.

-, Abenteuer und Entdeckungen in Sahara und Atlas, Köln 1928.

OTEYZA, Luis de, Abd-el-Krim y los prisioneros. Una información periodística en el campo enemigo, Melilla 2000 (Nachdr. d. Ausg. Madrid 1922).

PARENT, Pierre, Au Riff, in: Mercure de France 193 (1927) S. 26-56, S. 303-336, S. 558588; 194 (1927) S. 74-110.

REGUERT, Paul F., L'agression riffaine en 1925. Quelques réflexions et episodes, Paris 1933. ROGER-MATHIEU, Jacques, Le »Matin« chez Abd el Krim. Un important entretien avec le frère d'Abd el Krim et son premier ministre, in: Matin, 3.9.1925.

-, La périlleuse traversée des lignes espagnoles. Un combat de nuit sur la route de Msouha, in: Matin, 6.9.1925.

-, Les trois étapes de Msouha à Chechaouen. L'initiation aux particularités de la vie rifaine, in: Matin, 8.9.1925.

-, Cinq jours à Chechaouen. L'organisation de l'armée, entraînée et dirigée par des étrangers, in: Matin, 13.9.1925.

-, Le capitaine Gordon-Canning porteur d'une lettre d'Abd el Krim est arrivé à Marseille, in: Matin, 22.12.1925.

-, Mémoires d'Abd el Krim, Paris 1927.

RUE, Larry, Tribune Gets Peace Terms of Riffians, in: Chicago Tribune, 23.6.1925.

-, Riff Warriors Make Big Hauls. Tribune Man Views War Spoils, in: Chicago Tribune, 25.6.1925.

-, I Fly for News, New York 1932.

RYDER, Charles F., The War and International Good Faith. On the Efforts Which Are Being Made for a Conference of the Neutral Powers, London 1914.

-, The War and Christianity, Leeds 1915.

-, The Price of Victory, London 1916.

SABLOTNY, Richard, Légionnaire in Morocco, Los Angeles 1940.

SEGONZAC, René de, En zone espagnole. De Raïssouli à Abd el Kerim, in: Revue de Paris 32 (1925) S. 253-282.

SEHRING, Franz, Auf den Schlachtfeldern Marokkos. Die Leiden eines Deutschen in der spanischen Fremdenlegion. Erzählt nach eigenen Erlebnissen, Gumbinnen 1925.

SHEEAN, Vincent, Abd-el-Krim's Terms Get Out of Morocco, in: Chicago Tribune, 7.2.1925.

-, Riff Sultan Says War With France is Inconceivable, in: Chicago Tribune, 8.2.1925.

-, Raisuli, Best Bad Man, Faces Treason Trial, in: Chicago Tribune, 9.2.1925.

-, Chief Raisuli Refuses to Eat, Prays for Death, in: Chicago Tribune, 10.2.1925.

-, Arab Chieftain Puts >Tribune (Man in Prison, in: Chicago Tribune, 11.2.1925.

-, Riffis Fight with Captured Spanish Arms, in: Chicago Tribune, 12.2.1925.

-, Riff Laughs at Spanish Air Raids, in: Chicago Tribune, 13.2.1925.

-, Riff General Gives Views on de Rivera, in: Chicago Tribune, 14.2.1925.

-, Dashes Through Spanish Lines, in: Chicago Tribune, 15.2.1925.

-, Spanish Dead Heaped on Riff, in: Chicago Tribune, 16.2.1925.

-, Rivera Outlines Peace Terms, in: Chicago Tribune, 17.2.1925.

-, Im Rif, in: Neue Zürcher Zeitung, 29.9.1925.

-, Die Lage im Rif, in: Neue Zürcher Zeitung, 1.10.1925. 
-, Im Hauptquartier der Rifarmee. Durch die Feuerlinien zu Abd-el-Krim, in: Berliner Tageblatt, 2.10.1925.

-, Im Lager Abd-el-Krims, in: Neue Zürcher Zeitung, 21.10.1925.

-, Vor dem Fall von Aschdir. Unterredung mit Abd-el-Krim, in: Berliner Tageblatt, 21.10.1925.

-, A Declaration from Abd el Kader Tazi, in: Daily Express, 5.11.1925.

-, Die Armee Abd el Krims, in: Neue Zürcher Zeitung, 8.11.1925.

-, Abd el Krims europäische Helfer. Die Rolle der Ausländer im Rif, in: Neue Freie Presse, 10.11.1925.

-, Die Lage in Marokko, in: Neue Zürcher Zeitung, 16.11.1925.

-, Frankreichs Friedensbedingungen für Abd-el-Krim, in: Neue Zürcher Zeitung, 26.11.1925.

-, Condition for an Armistice, in: Al Moghreb al-Aksa \& Tangier Gazette, 5.12.1925.

-, My Meeting with Abdel-Krim. The Hieratic, »Semilegendary« Riffi Sultan and his PirateLike Gun-Runners, in: Asia 25 (1925) S. 845-857, S. 878-885.

-, »Robin Hood" of the Riff. The "German Pilgrim«, Aid to Abd el-Krim and to the Riffi, WGreat Man«, His Brother, in: Asia 25 (1925) S. 969-980, S. 984-988.

-, Eye to Eye with the Barbary Pirate, Raisuli. Impressions of the Most Evil Old Chief in Morocco after his Capture by Abd el-Krim, in: Asia 25 (1925) S. 1071-1079.

-, Abd el Krim and the War in Africa, in: The Atlantic Monthly 136 (1925) S. 251-263.

-, An American among the Riffi, New York, London 1926.

-, Peace in Morocco, in: Asia 26 (1926) S. 210f., S. $259 \mathrm{f}$.

-, Personal History, New York 1940.

ShELDRAKE, Khalid, The British Muslim Society. Public Meeting in the Mosque, Woking, in: Islamic Review and Muslim India 3 (1915) S. 4-7.

-, Our Duty To-day, in: Islamic Review 9 (1921) S. 71-74.

-, Muhammad a True Man, in: Islamic Review 9 (1921) S. 197-200.

-, People of the Book, in: Islamic Review 9 (1921) S. 252-255.

-, The New Era in the West, in: Islamic Review 9 (1921) S. 322-326.

-, Islam and the Unity of Mankind, in: Islamic Review 9 (1921) S. 373-377.

-, Practical Experience of Islam, in: Islamic Review 9 (1921) S. 420-423.

SIEGELER, H., Die Erlebnisse eines deutschen Fremdenlegionärs in Spanisch-Marokko, in: Hamburger Volkszeitung, 26.1.1925.

SIMON, Général, Pacification du Rif. Soumission d'Abd el Krim, in: Revue des vivants 4 (1930) S. 327-334.

SPENCER PRYSE, Gerald, Through the Lines to Abd-el-Krim's Stronghold in the Riff. A Journey Recently Undertaken in a Little-Known Country, in: Blackwoods Magazine 218 (1925) S. 437-476, S. 619-646, S. 839-861.

TERHORST, Bernd, Spaniens Kampf um Marokko, in: Die Woche 26 (1924) S. 1002-1006.

-, Bei den Rifkabylen. Vom Schauplatz der Kämpfe in Spanisch-Marokko, in: Die Woche 26 (1924) S. 1060-1062.

-, Feuer am Rif. Zwei Jahre unter Rifkabylen, Berlin 1925.

VOINOT, Louis, Sur les traces glorieuses des pacificateurs du Maroc, Paris 1939.

WARD, John, With the »Die-Hards« in Siberia, London 1920.

WARD PRICE, George, First News from the Riff, in: Daily Mail, 24.4.1924.

-, Rich Setting in Wilds, in: Daily Mail, 25.4.1924.

-, The Journey, in: Daily Mail, 26.4.1924.

-, Midnight in Morocco, in: Daily Mail, 28.4.1924.

-, How Peace Might Come to Morocco, in: Daily Mail, 1.5.1924. 
-, In Morocco with the Legion, London 1934.

-, Extra-Special Correspondent, London u.a. 1957.

WOLFF, Hans F., Mit der spanischen Flotte vor Kap Morro (In der Bucht von Alhucemas), in: Illustrirte Zeitung 165 (1925) S. 508-512.

-, Bei den Spaniern in Marokko. Der Vorstoß zum Djebel Malmusi, in: Illustrirte Zeitung 165 (1925) S. $584 f$.

-, Bei den Spaniern in Marokko. Der Sektor von Ajdir, in: Illustrirte Zeitung 165 (1925) S. 694.

-, Die Lage im Innern des Rifgebiets, in: Ilustrirte Zeitung 165 (1925) S. 774-778.

-, Das Gesicht des Rif, Berlin 1927.

ZAEPER, Alfred, Unter der Glutsonne Marokkos gegen Abd el Krim, Leipzig 1932.

Zeltin, Otto, Der Tausend-Meilen-Ritt durch die Sahara. Auf nie betretenen Pfaden, Dresden 1927. 